
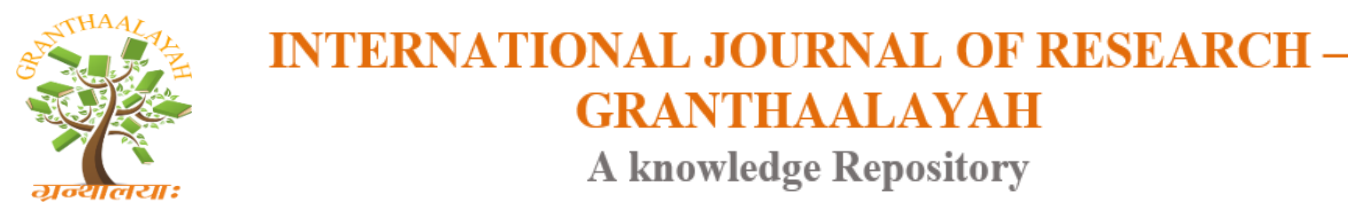

Management

\title{
A STUDY ON IMPACT OF PSYCHOLOGICAL EMPOWERMENT ON EMPLOYEE RETENTION IN TECHNICAL INSTITUTES OF DURG AND BHILAI
}

\author{
Shivangi Jaiswal ${ }^{* 1}$, Pankaj Joge ${ }^{2}$ \\ ${ }^{*}$ Student, PG Department of Commerce, St Thomas College Bhilai, Chhattisgarh, India \\ ${ }^{2}$ Assistant Professor, Faculty of Management Studies, Shri Shankaracharya Group of \\ Institutions, Bhilai (C.G.), India
}

\begin{abstract}
Psychological empowerment is the oil that lubricates the exercise of learning. Talented and psychological empowered human capital is becoming the prime ingredient of organizational success. If an employee is psychologically empowered, that means that he feels free to express his ideas and thus the employees would perform better in the job. Psychological empowered human capital is becoming the prime ingredient of organizational success. A critical feature of successful teams, especially in knowledge-based enterprises, is that they are invested with a significant degree of psychological empowerment, or decision-making authority. Psychologically empowered employees are always an asset to any organization because they will be self-driven and motivated to perform well in their work. This research will enable us to know what the impacts of psychological empowerment on employee retention are. For the research, the sample units were 75 faculties of 5 technical institutes in Durg and Bhilai. Questionnaire was used to collect the data. The analysis of the data was done through SPSS software, using Regression analysis. Through this research it was found that psychological empowerment does contribute to employee retention.
\end{abstract}

Keywords: Faculty Members; Psychological Empowerment; Employee Retention; Technical Educational Institutes.

Cite This Article: Shivangi Jaiswal, and Pankaj Joge. (2018). "A STUDY ON IMPACT OF PSYCHOLOGICAL EMPOWERMENT ON EMPLOYEE RETENTION IN TECHNICAL INSTITUTES OF DURG AND BHILAI." International Journal of Research Granthaalayah, 6(1), 470-479. https://doi.org/10.29121/granthaalayah.v6.i1.2018.1656.

\section{Introduction}

Psychological empowerment has its roots in early work on employee alienation and quality of work life. Rather than focusing on managerial practices that share power with employees at all levels, the psychological perspective is focused on how employees experience empowerment at work. This perspective refers to empowerment as the personal beliefs that employees have about 
their role in relation to the organization. When people feel empowered at work, they experience four dimensions including: meaning, self-determination, competence, impact.

Psychological empowerment is the oil that lubricates the exercise of learning. Talented and psychological empowered human capital is becoming the prime ingredient of organizational success. A critical feature of successful teams, especially in knowledge-based enterprises, is that they are invested with a significant degree of psychological empowerment, or decision-making authority.

Psychological empowerment can be described as giving employees' authority to make decisions about their work without supervisory approval. Good managers are expected to help employees refine their job achievements by encouraging, instructing, guiding and giving them advice. Psychological empowerment can increase employees' motivation, job satisfaction, and loyalty to their companies.

The purpose of taking this topic of research is because psychological empowerment is one such factor which would help employers in retaining good employees. Psychological empowerment is something which is developed from within the employees so it is very important to know as an employer to understand what are the factors that would contribute to the development of psychological empowerment.

\section{Literature Review}

The concept of psychological empowerment can trace its origins to the related organizational theories of participative management and employee involvement (e.g., Cotton, 1993; Wagner, 1994). Initially, organizational theorists defined empowerment in a unidimensional manner in terms of self-efficacy (Conger \& Kanungo, 1988) or self-determination (Macher, 1988). More recently however, psychological empowerment has been defined as a multi-dimensional motivational construct consisting of four distinct cognitive dimensions (Spreitzer, 1995, 1996; Thomas \& Velthouse, 1990).

Psychological Empowerment is defined as a motivational construct manifested in four cognitions

- Meaning

- Competence

- Self-determination

- Impact

\subsection{Meaning}

Meaning is the value of a work goal or purpose, judged in relation to an individual's own ideals or standards (Thomas \& Velthouse, 1990). Meaning involves a fit between the requirements of a work role and beliefs, values, and behaviors.

\subsection{Competence}

Competence, or self-efficacy, is an individual's belief in his or her capability to perform activities with skill (Gist, 1987). Competence is analogous to agency beliefs, personal mastery, or effort- 
performance expectancy (Bandura, 1989). This dimension is labeled competence here rather than self-esteem because I focused on efficacy specific to a work role rather than on global efficacy.

\subsection{Self-determination}

Where competence is a mastery of behavior, self-determination is an individual's sense of having choice in initiating and regulating actions (Deci, Connell, \& Ryan, 1989). Self-determination reflects autonomy in the initiation and continuation of work behaviors and processes; examples are making decisions about work methods, pace, and effort.

\subsection{Impact}

Impact is the degree to which an individual can influence strategic, administrative, or operating outcomes at work (Ashforth, 1989). Impact is the converse of learned helplessness (Martinko \& Gardner, 1982). Further, impact is different from locus of control; whereas impact is influenced by the work context; internal locus of control is a global personality characteristic that endures across situations (Wolfe \& Robertshaw, 1982).

Together, these four cognitions reflect an active, rather than a passive, orientation to a work role. By active orientation, means an orientation in which an individual wishes and feels able to shape his or her work role and context. The four dimensions are argued to combine additively to create an overall construct of psychological empowerment. In other words, the lack of any single dimension will deflate, though not completely eliminate, the overall degree of felt empowerment. Thus, the four dimensions specify a "nearly complete or sufficient set of cognitions" for understanding psychological empowerment (Thomas \& Velthouse, 1990).

Meaning or purpose refers to a person's perceived congruence between personal work roles and personal beliefs, values, and behaviors (Brief \& Nord, 1990). Competence refers to one's perceptions of possessing the capabilities to perform a specific job or task well (Gist, 1987) and is conceptually similar to the idea of personal mastery or self-efficacy (Bandura, 1986). Selfdetermination involves the belief that one has control, choice, or autonomy over one's work behaviors and processes (Deci \& Ryan, 1985; Greenberger, Strasser, Cummings, \& Durham, 1989). Finally, impact relates to one's perception of having made a difference by influencing strategic, administrative or operating outcomes at work (Ashford, 1989). Taken together, these four cognitive dimensions comprise the basic essence of psychological empowerment in the workplace.

Viewed in this way, psychological empowerment is not a stable and generalizable personality trait, but rather a cognitive state created by a set of malleable cognitions that are shaped on an ongoing basis by one's work environment (Thomas \& Velthouse, 1990). Furthermore, these dimensions combine in an additive way such that a person who lacks one dimension will simply experience fewer empowerment cognitions, rather than no empowerment cognitions at all (Spreitzer's, 1995). In other words, psychological empowerment is a continuous variable that reflects the degree empowerment felt, rather than the presence or absence of empowerment (Spreitzer's, 1995). Finally, psychological empowerment results in an active, not passive, 
approach to work that causes individuals to strive toward and feel capable of shaping work roles and work contexts (Spreitzer's, 1995).

Spreitzer's (1995) renamed the meaningfulness cognition using instead the term meaning, defined as the value of a work goal or purpose judged in relation to an individual's own ideals or standards. This cognition involves a fit between the requirements of one's work role and one's values, beliefs, and behaviors. Self-determination is an $\mathrm{n}$ individual's sense of having control over how work is accomplished and is related to the choice cognition as put forth by Thomas and Velthouse (1990). Competence, or self-efficacy, is the belief that an employee is capable of performing work activities with skill. Finally, impact is the degree to which an individual can influence strategic, administrative, or operating outcomes at work (Spreitzer's, 1995; Spreitzer's, Kizilos, \& Nason, 1997). Spreitzer's (1995) uses these cognitions to define psychological empowerment. She argues that the four cognitions combine additively to create an overall construct of psychological empowerment as "a motivational construct manifested in four cognitions" (Spreitzer's, 1995,)

\section{Psychological Empowerment and Job Satisfaction}

Psychological empowerment has been found to be significantly related to job satisfaction, however, the individual constructs have received varied results (Carless2004; Seibert, Silver, \& Randolph, 2004; Liden, Lucas, \& Sparrowe, 2000; Spreitzer's etal., 1997).

\section{Job Satisfaction and Employee Retention}

Job satisfaction is a highly researched work attitude and is commonly defined as "a pleasurable or positive emotional state resulting from the appraisal of one's job or job experiences" (Locke, 1976, p. 1304). Job satisfaction is associated with various organizational and individual outcomes (Judge, Parker, Colbert, Heller, \& Ilies, 2001). For example, Violanti and Aron (1994) found that high levels of job satisfaction were associated with improved psychological wellbeing, in their research with police officers. The relationship between low levels of job satisfaction and increased turnover behaviours is consistently produced (O'Leary-Kelly \& Griffith, 1995), However, the associations between job satisfaction and actual turnover behaviour are generally only moderate, and have also produced some mixed findings. The instability of job satisfaction over time probably accounts for these moderate predictions of turnover (O'Driscoll \& Brough, 2003; Paton, Jackson, \& Johnston, 2003), although this point has rarely been formally tested. 
RESEARCH INSTRUMENT

\begin{tabular}{|c|c|c|c|}
\hline INDEPENDENT VARIABLE & SOURCE & CONCEPT & DEPENDENT VARIABLE \\
\hline MEANING & $\begin{array}{l}\text { Thomas \& } \\
\text { Velthouse, } 1990 .\end{array}$ & $\begin{array}{l}\text { Meaning is the value of a } \\
\text { work goal or purpose, judged } \\
\text { in relation to an individual's } \\
\text { own ideals or standards. It } \\
\text { involves a fit between the } \\
\text { requirements of a work role } \\
\text { and beliefs. values, and } \\
\text { behaviors. }\end{array}$ & \multirow{4}{*}{$\begin{array}{l}\text { PSYCHOLOGICAL } \\
\text { EMPOWERMENT }\end{array}$} \\
\hline COMPETENCE & $\begin{array}{l}\text { Gist, } 1987, \\
\text { Bandura, } 1989\end{array}$ & $\begin{array}{l}\text { Competence, or self-efficacy, } \\
\text { is an individual's belief in his } \\
\text { or her capability to perform } \\
\text { activities with skill. It is } \\
\text { analogous to agency beliefs. } \\
\text { personal mastery, or effort- } \\
\text { performance expectancy. }\end{array}$ & \\
\hline SELF-DETERMINATION & $\begin{array}{l}\text { Deci, Connell, \& } \\
\text { Ryan, 1989, } \\
\text { Bell\&Staw,1989: } \\
\text { Spector, } 1986\end{array}$ & $\begin{array}{l}\text { Self-determination is an } \\
\text { individual's sense of having } \\
\text { choice in initiating and } \\
\text { regulating actions. It reflects } \\
\text { autonomy in the initiation, } \\
\text { continuation of work } \\
\text { behaviors and processes. }\end{array}$ & \\
\hline IMPACT & $\begin{array}{l}\text { Ashforth. } 1989 . \\
\text { Martinko \& } \\
\text { Gardner, } 1982\end{array}$ & $\begin{array}{l}\text { Impact is the degree to which } \\
\text { an individual can influence } \\
\text { strategic, administrative, or } \\
\text { operating outcomes at work. } \\
\text { It is the converse of learned } \\
\text { helplessness. }\end{array}$ & \\
\hline
\end{tabular}

\begin{tabular}{|l|l|l|l|}
\hline $\begin{array}{l}\text { INDEPENDENT } \\
\text { VARIABLE }\end{array}$ & SOURCE & CONCEPT & $\begin{array}{l}\text { DEPENDENT } \\
\text { VARIABLE }\end{array}$ \\
\hline PSYCHOLOGICAL & $\begin{array}{l}\text { Thomas \& } \\
\text { Eelthouse, } \\
\text { A cognitive model of empowerment in } \\
\text { which increased intrinsic task } \\
\text { motivation is manifested in four } \\
\text { cognitions: meaningfulness, } \\
\text { competence and impact. Psychological } \\
\text { empowerment is not a stable and } \\
\text { generalizable personality trait, but } \\
\text { rather a cognitive state created by a set } \\
\text { of malleable cognitions that are shaped } \\
\text { on an ongoing basis by one's work } \\
\text { environment.( Spreitzer's, 1995) }\end{array}$ & SAT \\
\hline 1990 & & SASFACTION \\
\hline
\end{tabular}




\begin{tabular}{|l|l|l|l|}
\hline $\begin{array}{l}\text { INDEPENDENT } \\
\text { VARIABLE }\end{array}$ & SOURCE & CONCEPT & $\begin{array}{l}\text { DEPENDENT } \\
\text { VARIABLE }\end{array}$ \\
\hline PSYCHOLOGICAL & $\begin{array}{l}\text { Thomas \& } \\
\text { Velthouse, } \\
\text { EMPOWERMENT }\end{array}$ & $\begin{array}{l}\text { A cognitive model of empowerment in } \\
\text { which increased intrinsic task } \\
\text { motivation is manifested in four } \\
\text { cognitions: meaningfulness, } \\
\text { competence and impact. Psychological } \\
\text { empowerment is not a stable and } \\
\text { generalizable personality trait, but } \\
\text { rather a cognitive state created by a set } \\
\text { of malleable cognitions that are shaped } \\
\text { on an ongoing basis by one's work } \\
\text { environment. (Spreitzer's, 1995) }\end{array}$ & SOBTISFACTION \\
\hline
\end{tabular}

\section{Research Objectives}

1) To analyze the impact of psychological empowerment on job satisfaction.

2) To analyze the impact of job satisfaction on employee retention.

3) To suggest employee retention strategies by enhancing psychological empowerment among employees of technical institutes.

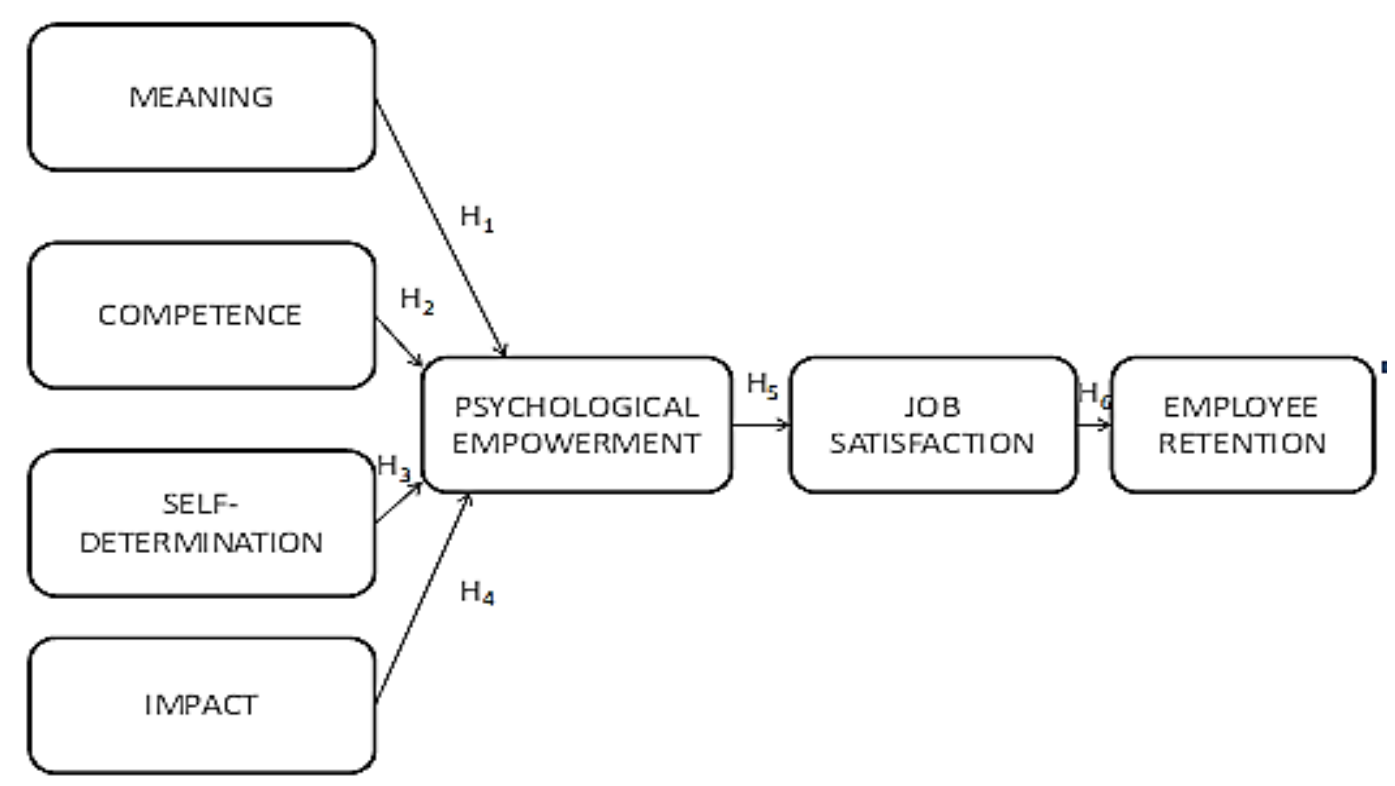

Figure 1: model on psychological empowerment

\section{Research Hypothesis}

$\mathbf{H}_{\mathbf{1}}$ : There is no significant impact of meaning on psychological empowerment.

$\mathbf{H}_{2}$ : There is no significant impact of self-determination on psychological empowerment.

$\mathbf{H}_{3}$ : There is no significant impact of competence on psychological empowerment. 
$\mathbf{H}_{4}$ : There is no significant impact of impact on psychological empowerment.

H5: There is no significant relationship between psychological empowerment and job satisfaction.

$\mathbf{H}_{6}$ : There is no significant relationship between job satisfaction and employee retention.

\section{Research Plan}

\section{Research Design}

The research design used in the research is exploratory research and descriptive research. Exploratory research has been used initially for identification of factors and for the development of model. The descriptive research was used to collect the data, which was through questionnaire so as to identify the relationship between psychological ownership and employee retention.

\section{Data Collection Method}

The data has been collected using survey method.

\section{Research Instrument}

In this research, questionnaire has been used as the research instrument.

\section{Measurement Scale}

The scaling technique used is Likert scale 1-5.

\section{Sample Plan}

\section{Sampling design}

The sampling design used is non-probability convenience sampling.

\section{Sample Size}

The sample size is 75 i.e. 15 lecturers from five colleges of Durg and Bhilai.

\section{Data Analysis and Result}

Table 1: Factor Analysis

\begin{tabular}{|l|l|l|l|l|}
\hline \multicolumn{5}{|c|}{ Rotated Component Matrix } \\
\hline & \multicolumn{4}{|c|}{ Component } \\
\hline & 1 & 2 & 3 & 4 \\
\hline MNG1 & .678 & .187 & .066 & .145 \\
\hline MNG2 & .576 & .151 & -.084 & .074 \\
\hline MNG3 & .497 & -.105 & -.228 & .563 \\
\hline MNG4 & .718 & .162 & .040 & -.048 \\
\hline CPT1 & .697 & -.088 & .308 & .213 \\
\hline CPT2 & -.133 & .644 & .283 & .362 \\
\hline SDT1 & .084 & .233 & -.028 & .821 \\
\hline SDT2 & .045 & .384 & .755 & -.080 \\
\hline
\end{tabular}




\begin{tabular}{|l|l|l|l|l|}
\hline IPT1 & .197 & -.085 & .578 & .529 \\
\hline IPT2 & .011 & -.012 & .803 & -.056 \\
\hline JST1 & .344 & .721 & .157 & -.004 \\
\hline ERT1 & .220 & .018 & -.089 & .812 \\
\hline $\begin{array}{l}\text { Extraction Method: Principal Component Analysis. } \\
\text { Rotation Method: Varimax with Kaiser Normalization. }\end{array}$ \\
Rotation converged in 6 iterations. \\
\hline
\end{tabular}

\section{Interpretation}

On applying factor analysis, it has been found that four items of meaning variable are loaded under component 1. Competence and Self-determination variables are weekly loaded or scattered in different components, so will not be considered. Two items of Impact variable are loaded under $3^{\text {rd }}$ component, whereas job satisfaction is loaded under $2^{\text {nd }}$ component and employee retention is loaded under $4^{\text {th }}$ component. Therefore, after factor analysis four items of meaning, two items of impact, job satisfaction and employee retention will be considered for further multivariate analysis. (Table No.-1)

Table 2: Regression

\begin{tabular}{|c|c|c|c|c|c|}
\hline \multicolumn{6}{|c|}{ Coefficients } \\
\hline \multirow{2}{*}{ Model } & \multicolumn{2}{|c|}{ Unstandardized Coefficients } & \multirow{2}{*}{\begin{tabular}{|l|} 
Standardized Coefficients \\
Beta
\end{tabular}} & \multirow{2}{*}{$\mathbf{T}$} & \multirow{2}{*}{ Sig. } \\
\hline & B & Std. Error & & & \\
\hline (Constant) & .626 & 1.005 & & .623 & .535 \\
\hline $1 \mathrm{MNG}$ & .609 & .214 & .317 & 2.844 & 4.006 \\
\hline IPT & .176 & .166 & .118 & 1.056 & 5.295 \\
\hline
\end{tabular}

\section{Interpretation}

By performing regression analysis, it has been found that significant value of the variable meaning (0.006) is less than 0.05. It means meaning has a significant impact on job satisfaction. (Table No.-2)

Table 3: Regression

\begin{tabular}{|c|c|c|c|c|c|}
\hline \multicolumn{6}{|c|}{ Coefficients } \\
\hline \multirow{2}{*}{ Model } & \multicolumn{2}{|c|}{ Unstandardized Coefficients } & \multirow{2}{*}{$\begin{array}{l}\text { s } \\
\text { Standardized Coefficients } \\
\end{array}$} & & \multirow{2}{*}{ Sig. } \\
\hline & B & Std. Error & & & \\
\hline (Constant) & 1.949 & .360 & & 5.409 & 9.000 \\
\hline $1 /$ JST & .459 & .091 & .508 & 5.035 & 5.000 \\
\hline
\end{tabular}

\section{Interpretation}

In table-3, it has been found that the significant value of job satisfaction (.000) is less than 0.05 . It means, job satisfaction has a significant impact on employee retention. (Table No-3) 


\section{Findings}

1) Meaning as a variable of psychological empowerment has significant impact on it, since the p (sig.) value of "Meaning" is 0.006 is less than 0.05 (at 5\% significant level, refer table no.-2).

2) Job Satisfaction has significant impact on Employee Retention as p (sig.) value is 0.000 is less than .050 (at 5\% significant level, refer table no.-3).

\section{Recommendations}

Institutes should focus more on developing such culture in the organization which would actually facilitate the development of psychological empowerment in the institute.

From this research it has been found that meaning is the only variable which has its Impact on psychological empowerment. Institute should adopt strategies to increase psychological empowerment. Institutes should give importance to the opinion given by employees in departmental decision making. They should also give autonomy to employee to take decisions regarding their job. By adopting this strategy institutes can increase psychological empowerment and also increase job satisfaction which in-turn will help in retaining employees.

\section{Limitations}

1) The sample size had to be limited to 75 faculties because of limitation of time.

2) Some respondents were not willing to fill the questionnaire because of time.

3) All the factors could not be covered because it would increase the length of the questionnaire.

\section{Conclusion}

This study focuses on impact of psychological empowerment on retention. It also includes the study of impact of various variables of psychological empowerment on it. It has been found that meaning has its impact, while impact variable does not have any significant impact on it. The other two variables i.e. competence and self-determination were not included as they were scattered in different components in factor analysis. As psychological empowerment is the oil that lubricates the exercise of learning, so it is important to develop psychological empowerment in employees. As a result of this psychological empowerment contribute to job satisfaction of an employee.

Similarly job satisfaction has a significant relation with retention of an employee. It means if an employee feels psychologically empowered, then it will contribute to job satisfaction which in turn will help the institute in retaining its employees. Hence from this research it can be concluded that psychological empowerment is an important aspect for retaining employees in the institute. 


\section{References}

[1] Thomas, K. W., \& Velthouse, B. A., (1990). Cognitive elements of empowerment. Academy of Management Review.

[2] Spreitzer's, G. M., Kizilos, M. A., \& Nason, S. W. (1997). A Dimensional Analysis of the Relationship between Psychological Empowerment and Effectiveness, satisfaction, and Strain. Journal of Management, 23(5), 679-705.

[3] Academy of Management Journal, Publication, 1995, Author: Spreitzer, Gretchen M.

[4] Spreitzer, Gretchen M. (1995). Psychological empowerment in the workplace: Dimensions, measurement, and validation. Academy of Management Journal, 38, 14421465.

[5] Thomas, K.W. \& Velthouse, B.A. (1990). Cognitive elements of empowerment. Academy of Management Review, 15, 666-681.

[6] Spreitzer, Gretchen M. (1995). Psychological empowerment in the workplace: Dimensions, measurement, and validation. Academy of Management Journal, 38(5): 1442-1465.

[7] Spreitzer, Gretchen M. (1996). Social structural characteristics of psychological empowerment. Academy of Management Journal, 39(2): 483-504.

*Corresponding author.

E-mail address: shivangi.j08690@ gmail.com/pankaj.joge@ gmail.com 